Original

\title{
Tongue Carcinogenic Susceptibility of p53 Deficient Mice to Methyl-n-amylnitrosamine
}

\author{
Norimitsu Shirai ${ }^{1,2}$, Tetsuya Tsukamoto ${ }^{1}$, Masami Yamamoto ${ }^{1}$, Takeshi Iidaka ${ }^{1,2}$, \\ Hiroki Sakai ${ }^{1,2}$, Tokuma Yanai ${ }^{2}$, Toshiaki Masegi², Lawrence A. Donehower ${ }^{3}$, and \\ Masae Tatematsu ${ }^{1}$ \\ ${ }^{1}$ Division of Oncological Pathology, Aichi Cancer Center Research Institute, 1-1 Kanokoden, Chikusa, Nagoya \\ 464-8681, Japan \\ ${ }^{2}$ Department of Veterinary Pathology, Gifu University, Yanagido 1-1, Gifu, 501-1193, Japan \\ ${ }^{3}$ Department of Molecular Virology and Microbiology, Baylor College of Medicine, Houston, Texas 77030, U.S.A.
}

\begin{abstract}
Mutation of the $\mathrm{p} 53$ tumor suppressor gene is a common genetic alteration in human squamous cell carcinoma of the tongue. Mice deficient in p53 have recently attracted attention for their potential to identify chemical genotoxins. In this study we investigated the susceptibility of p53 nullizygous $(-/-)$, heterozygous $(+/-)$, and wild type (+/+) mice to methyl- $n$-amylnitrosamine (MNAN) induced squamous cell carcinoma (SCC) of the tongue. The p53 (+/-), and (+/+) mice were treated with 5 p.p.m. MNAN in drinking water for 8 weeks then held without further treatment for an additional 7 or 17 weeks, and killed at 15 or 25 experimental weeks. A separate group of the p53 (-/-) mice were given 5 p.p.m. MNAN for 8 weeks and were killed at 15 weeks. At 15 weeks, SCCs and papillomas were observed in 5/12 $(41.7 \%)$ and $2 / 12(16.7 \%)$ of $p 53(-/-)$ mice, respectively, but not in p53 (+/-) and (+/+) mice. At 25 weeks, carcinomas in situ (CIS) were detected in 1/16 (6.3\%) of p53 (+/-) and 1/13 (7.7\%) of p53 (+/+) mice, and a papilloma was observed in the $\mathrm{p} 53(+/-)$ mouse which had CIS. PCR-single strand conformation polymorphism analysis of exons $5-8$ of the p53 gene demonstrated a missense mutation in the CIS from p53 (+/+) mouse. These results suggest that a lack of p53 gene function predisposes the tongue to the development of SCCs in mice treated with MNAN, and show that p53 (-l-) mouse was a useful model for demonstrating carcinogenicity of MNAN to tongue. (J Toxicol Pathol 2002; 15: 209-214)
\end{abstract}

Key words: p53 knockout, mice, tongue, squamous cell carcinoma, methyl- $n$-amylnitrosamine

\section{Introduction}

The p53 tumor suppressor gene encodes a transcriptional regulator that prevents the propagation of genetically damaged cell ${ }^{1}$ and alterations in $\mathrm{p} 53$ gene have been reported in a wide range of human cancers ${ }^{2,3}$. The role of p53 includes contribution to G1 cell cycle arrest and induction of DNA repair genes in response to DNA damage as well as activation of genes promoting apoptosis ${ }^{1,4}$. Mutation of the p53 gene is a common genetic alteration in human squamous cell carcinoma of the tongue $e^{5-7}$. The frequencies of $\mathrm{p} 53$ mutations and consequent loss of wildtype $\mathrm{p} 53$ function are assumed to play a role in tongue SCC development. Mice with homozygous or heterozygous p53deficient were susceptible to the early onset of spontaneous tumors ${ }^{8}$. These animals have been a model for assessing the

Received: 2 September 2002, Accepted: 28 October 2002 Mailing address: Tetsuya Tsukamoto, Division of Oncological Pathology, Aichi Cancer Center Research Institute, 1-1 Kanokoden, Chikusa, Nagoya 464-8681, Japan

TEL: 81-52-752-6111 (ext. 7062) FAX: 81-52-763-5233

E-mail: ttsukamt@aichi-cc.jp function of p53 in tumor development and for identifying carcinogens $\mathbf{s}^{9-11}$. Nullizygous p53-deficient mice are highly susceptible to early onset of spontaneous tumors. By the age of 4.5 months, approximately half of the nullizygotes developed tumors and by 10 months of age, all of the mice died or developed tumors ${ }^{12}$. Most of these tumors consisted of lymphomas and sarcomas. Furthermore, great enhancement of malignant progression was reported in chemically induced skin tumors in the nullizygous p53deficient mice ${ }^{13}$. In contrast, the heterozygotes were viable and showed a low background incidence of spontaneous tumors up to almost 12 months of age ${ }^{8,14}$. The low background tumor incidence combined with the increased tumor susceptibility to chemically induced tumors make the p53 (+/-) mouse useful for short-term bioassay ${ }^{15,16}$. MNAN, an N-nitroso compound, is known to induce esophageal cancer in rats ${ }^{17}$, and in a previous study administration of

Abbreviations: KO, knockout; nullizygous, (-/-); heterozygous, (+/-); wild type $(+/+)$; MNAN, methyl-namylnitrosamine; PCR, polymerase chain reaction; SSCP, single strand conformation polymorphism; SCC, squamous cell carcinoma; CIS, carcinoma in situ. 
MNAN yielded cancers in esophagus of p53-deficient mice with higher incidence compared to wild-type counterparts ${ }^{18}$. Diffusion of MNAN into the esophagus is a possible factor in carcinogenesis. Considering that the tongue is directly exposed to MNAN in drinking water, cancers are likely to occur in tongue as well. In the present study we examined association of p53 deficiency with tongue cancer development in the p53 knockout mice following administration of MNAN.

\section{Materials and Methods}

\section{Animals}

p53 knockout mice on a C57BL/6 genetic background, produced by Donehower et al. ${ }^{19}$, were maintained at the Animal Facility of Aichi Cancer Center Research Institute. Six-week-old males were used in the experiment. They were housed in plastic cages with hardwood chips in an airconditioned room with a $12 \mathrm{~h}$ light- $12 \mathrm{~h}$ dark cycle and given basal diet (Oriental NMF, Oriental Yeast Co., Tokyo, Japan) and drinking water ad libitum. Genotyping of each mouse was performed as described earlier ${ }^{20}$.

\section{Carcinogen treatment}

MNAN was purchased from Sakai Rikagaku Institute (Fukui, Japan) and dissolved in drinking water weekly to achieve the desired concentrations. Drinking water containing 5 p.p.m. of MNAN was filled into black bottles and provided ad libitum to p53 (+/+) and (+/-) mice for 8 weeks. Mice were then maintained without further treatment for an additional 7 or 17 weeks, and killed at week 15 or 25 . A separate group of p53 (-/-) mice were also treated with 5 p.p.m. MNAN for 8 weeks and killed at week 15. These dose and duration of treatment had previously revealed significant increases in esophageal cancers in both p53 (-/-) and p53 (+/-) mice ${ }^{18}$. Three groups of control animals with p53 (+/+), p53 (+/-) or p53 (-/-) and additional two groups of control animals with p53 $(+/+)$ or p53 $(+/-)$ received unsupplemented drinking water and killed at week 15 and 25 , respectively. All mice were killed by exsanguinations under ether anesthesia. This experimental protocol was approved by the Aichi Cancer Center Animal Committee.

\section{Histopathological analysis}

At necropsy, tongue tissues were resected, fixed in 4\% paraformaldehyde in phosphate buffered saline, embedded in paraffin, sectioned and stained with hematoxylin and eosin for microscopic examination.

\section{PCR-single strand conformation polymorphism analysis (SSCP) \\ Tumor samples from p53 (+/+) and p53 (+/-) mice were} subjected to PCR-SSCP. PCR-SSCP was conducted basically as described previously ${ }^{21}$. Briefly, genomic DNA was extracted from tumor areas in paraffin sections with DEXPAT (Takara) ${ }^{22}$ as detailed elsewhere. Four pairs of PCR primers for mouse p53 exons 5-8 were designed based
Table 1. PCR Primers for SSCP Analysis of Mouse p53

\begin{tabular}{|c|c|c|c|}
\hline \multirow{2}{*}{$\begin{array}{l}\text { Target } \\
\text { Exon } 5\end{array}$} & \multirow{3}{*}{$\begin{array}{l}\text { sense } \\
\text { antisense }\end{array}$} & \multirow[b]{2}{*}{ 5, ТСТСТТC } & $\begin{array}{c}\text { Product } \\
\text { length (bp) }\end{array}$ \\
\hline & & & 214 \\
\hline & & 5'-AGGCGGTGTTGAGGGCTTAC-3' & \\
\hline \multirow[t]{2}{*}{ Exon 6} & sense & 5'-GGCTTCTGACTTATTCTTGC-3' & 181 \\
\hline & antisense & 5'-CAACTGTCTCTAAGACGCAC-3' & \\
\hline \multirow[t]{2}{*}{ Exon 7} & sense & 5'-TCACCTGGATCCTGTGTCTT-3' & 170 \\
\hline & antisense & 5'-CAGGCTAACCTAACCTACCA-3' & \\
\hline \multirow[t]{2}{*}{ Exon 8} & sense & 5'-ACTGCCTTGTGCTGGTCCTT-3' & 279 \\
\hline & antisense & 5'-GGAGAGGCGCTTGTGCAGGT-3' & \\
\hline
\end{tabular}

on the published sequence ${ }^{22}$ as listed in Table 1. PCR was performed with a Takara PCR Thermal Cycler MP (Takara) and products were electrophoresed in $0.625 \times \mathrm{MDE}$ polyacrylamide gels (FMC, Rockland, ME) with 5\% glycerol. These were run at room temperature for $18 \mathrm{~h}$ at $8 \mathrm{~W}$, dried, and applied to imaging plates, which were then analyzed with BAS 2500 (Fuji Film, Kanagawa, Japan).

\section{Direct sequencing}

Sequencing was performed with ABI PRISM 3100 using a BigDye Terminator v3.0 Cycle Sequencing Ready Kit (Applied Biosystems, Forester City, CA). Sequence data were analyzed with DNASIS software (Hitachi Software Engineering, Yokohama, Japan).

\section{Statistical analysis}

Data for incidences of histopathological lesions were analyzed by the Fisher's exact test method. Survival of each genotype mice was analyzed using the log rank test $\mathrm{t}^{23}$.

\section{Results}

\section{Mortality of each genotype}

Administration of 5 p.p.m. MNAN in drinking water was well-tolerated by both p53 (+/-) and p53 (+/+) mice. Survival was not significantly different between p53 $(+/-)$, and p53 (+/+) mice. However, eight p53 (-/-) mice were found dead until week 15 . These included 4 lymphomas, 1 subcutaneous sarcoma, and 3 unknown cause of death. The causes of death for two p53 (+/-) mice and one p53 (+/+) mouse were not determined because of cannibalism.

\section{Histopathological analysis}

The incidences of MNAN induced papillomas and squamous cell carcinomas of tongue are summarized in Table 2. Papillomas were characterized by the exophytic masses with fronds of proliferating epithelial cells (Fig. 1A). Squamous cell carcinomas were locally invasive tumors that sometimes extended deep into the lingual skeletal musculature (Fig. 1B). These tumors occurred at the dorsal, lateral or ventral surface from the middle through posterior tongue. At week 15, although no microscopic changes were observed in both p53 (+/+) and (+/-) mice, SCCs were found 
Table 2. Incidences of Lingual Neoplasms in p53 Knockout Mice Treated with MNAN

\begin{tabular}{|c|c|c|c|c|c|c|c|}
\hline \multirow{2}{*}{$\begin{array}{l}\text { Exp. } \\
\text { week }\end{array}$} & \multirow{2}{*}{$\begin{array}{l}\text { MNAN } \\
\text { (p.p.m.) }\end{array}$} & \multirow{2}{*}{$\begin{array}{c}\text { p53 } \\
\text { geno-type }\end{array}$} & \multirow{2}{*}{$\begin{array}{c}\text { No. } \\
\text { animals }\end{array}$} & \multirow{2}{*}{$\begin{array}{c}\text { No. }^{\mathrm{a}} \\
\text { examined }\end{array}$} & \multicolumn{3}{|c|}{ No. of mice with lesions (\%) } \\
\hline & & & & & Papilloma & $\mathrm{SCC}^{\mathrm{b}}$ & $\mathrm{CIS}^{\mathrm{c}}$ \\
\hline \multirow[t]{6}{*}{$15 \mathrm{~W}$} & 5 & $(+/+)$ & 13 & 13 & 0 & 0 & 0 \\
\hline & & $(+/-)$ & 17 & 15 & 0 & 0 & 0 \\
\hline & & $(-/-)$ & 20 & 12 & 2 & $5^{\mathrm{d}}$ & 0 \\
\hline & 0 & $(+/+)$ & 5 & 5 & 0 & 0 & 0 \\
\hline & & $(+/-)$ & 5 & 5 & 0 & 0 & 0 \\
\hline & & $(-/-)$ & 4 & 4 & 0 & 0 & 0 \\
\hline \multirow[t]{4}{*}{$25 \mathrm{~W}$} & 5 & $(+/+)$ & 14 & 13 & 0 & 0 & 1 \\
\hline & & $(+/-)$ & 16 & 16 & 1 & 0 & 1 \\
\hline & 0 & $(+/+)$ & 5 & 5 & 0 & 0 & 0 \\
\hline & & $(+/-)$ & 6 & 6 & 0 & 0 & 0 \\
\hline
\end{tabular}

a: Mice which died before the end of experiment were excluded, b: SCC: Squamous cell carcinoma, c: CIS: Carcinoma in situ, d: Significantly different from p53 (+/+); $\mathrm{P}<0.01$, and from p53 (+/-); $\mathrm{P}<0.05$, using the Fisher's exact test.

A

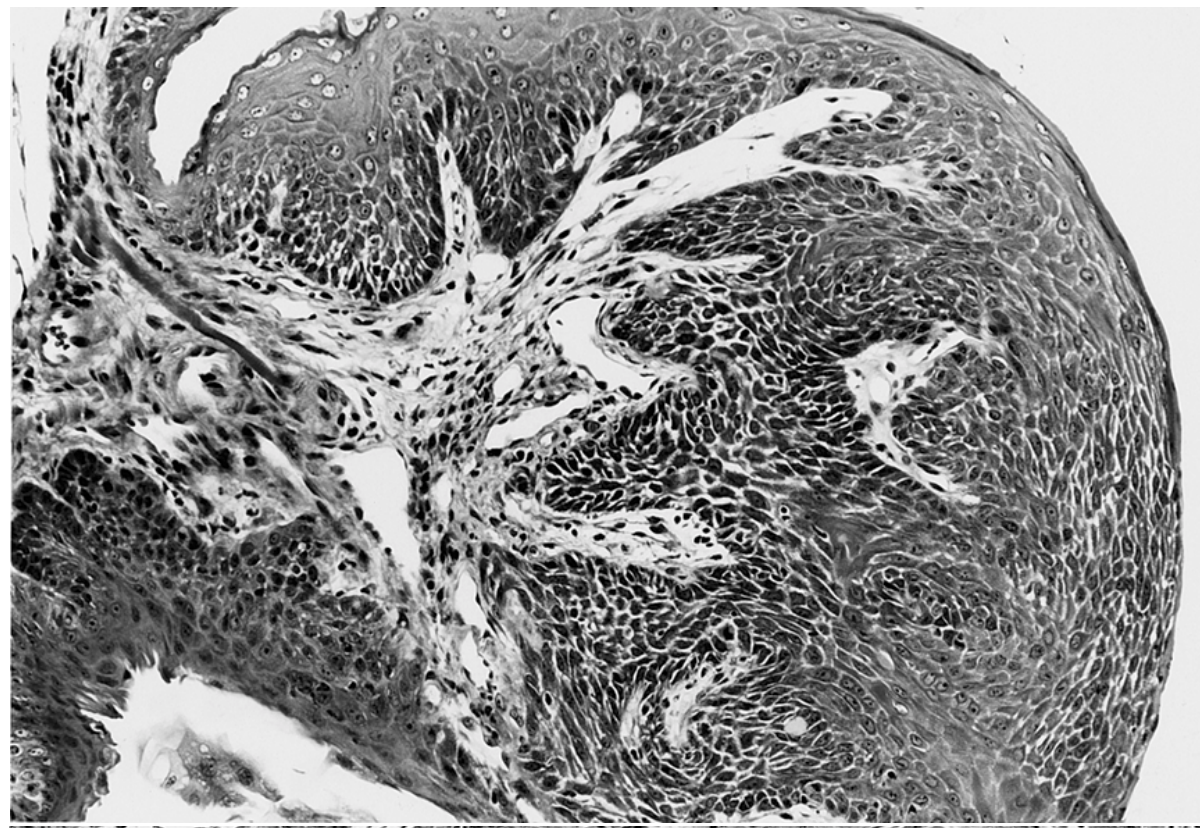

B

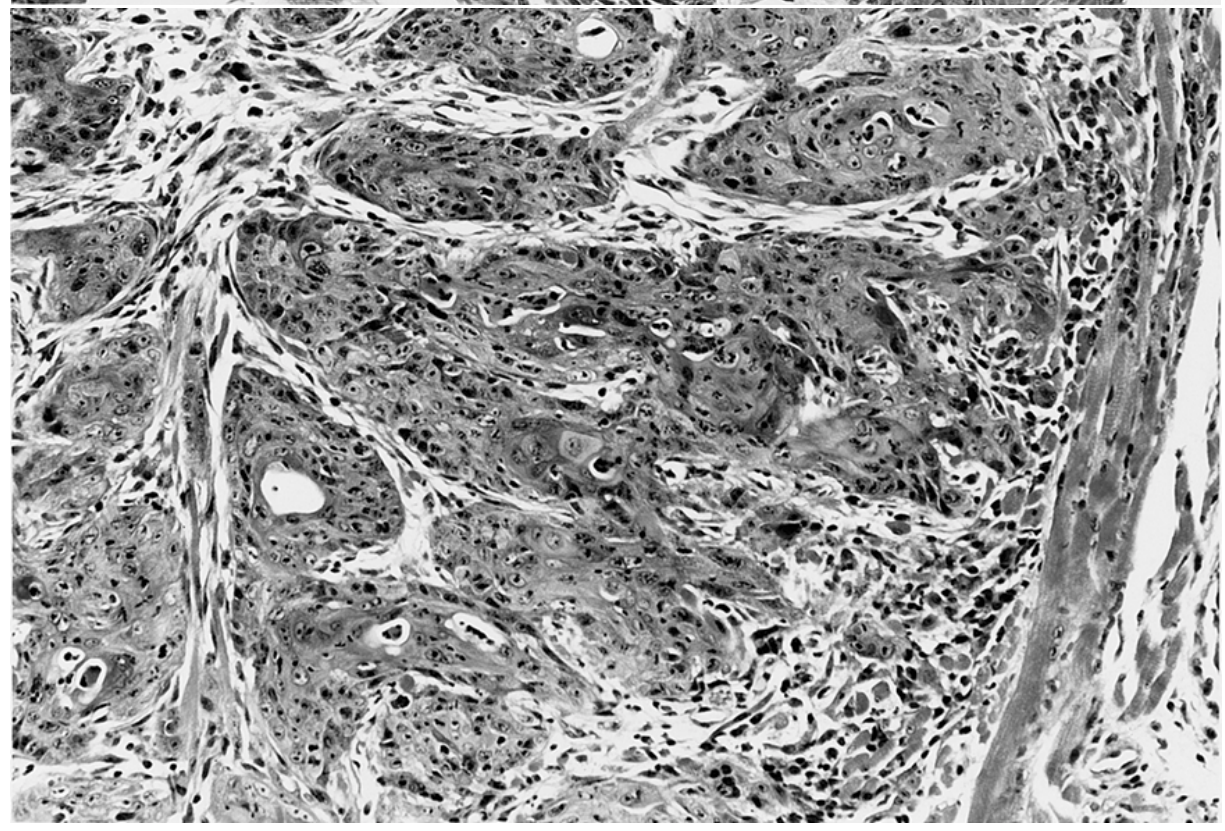

Fig. 1. Photomicrograph of papilloma at $40 \times(\mathrm{A})$, and squamous cell carcinoma at $100 \times(\mathrm{B})$. 
in $5 / 12(41.7 \%)$ p53 (-/-) mice and the incidence was significantly higher than that of p53 $(+/+)(\mathrm{P}<0.05)$ and p53 $(+/-)(\mathrm{P}<0.01)$. Additionally, 1 of $5 \mathrm{p} 53(-/-)$ mice that had SCCs and another p53 (-/-) mouse had papilloma. At week 25, carcinoma in situ (CIS) was observed in one of each p53 $(+/+)$ and (+/-) mice, and a papilloma was found in the p53 $(+/-)$ mouse which had CIS. CIS was characterized by intraepithelial growth of neoplastic cells with loss of polarity.

\section{PCR-SSCP analysis of the p53 gene in tumors}

PCR-SSCP and sequencing analyses for exons 5-8 of p53 gene were performed on 2 CIS samples obtained from one of each p53 (+/+) and (+/-) mice, and on a papilloma obtained from a p53 (+/-) mouse. p53 mutations were identified in a CIS of p53 (+/+) mouse, and in a papilloma of p53 (+/-) mouse (Table 3). DNA sequencing for the CIS from $\mathrm{p} 53(+/+)$ mouse revealed $\mathrm{CAC} \rightarrow \mathrm{TAC}$ transition at codon 211 in exon 6 resulting in the replacement of His by Tyr, a missense mutation (Fig. 2A). A papilloma from $\mathrm{p} 53$

Table 3. p53 Gene Mutations Identified in Lingual Tumors in Mice Treated with MNAN

\begin{tabular}{ccccccc}
\hline $\begin{array}{c}\text { Geno- } \\
\text { type }\end{array}$ & Histology & Exon & Codon & $\begin{array}{c}\text { Nucleotide } \\
\text { change }\end{array}$ & $\begin{array}{c}\text { Aminoacid } \\
\text { change }\end{array}$ & Event \\
\hline$+/+$ & CIS & 6 & 211 & CAC $\rightarrow$ TAC & His $\rightarrow$ Tyr & Transition \\
$+/-$ & CIS & - & - & - & - \\
$+/-$ & Papilloma & 7 & 254 & CTG $\rightarrow$ CTA & Leu $\rightarrow$ Leu & Transition \\
\hline
\end{tabular}

-: Mutation not detected in exons 5,6,7, and 8 .

A

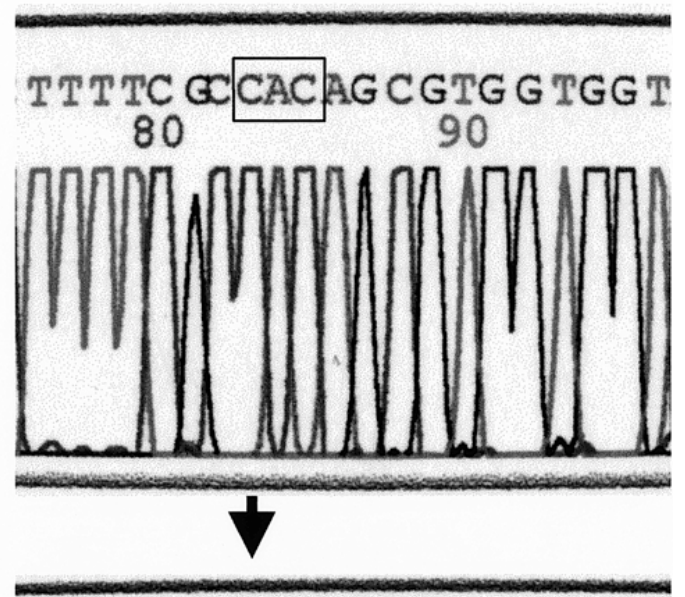

TT TTCGCTACA CG TGG TGGT 80

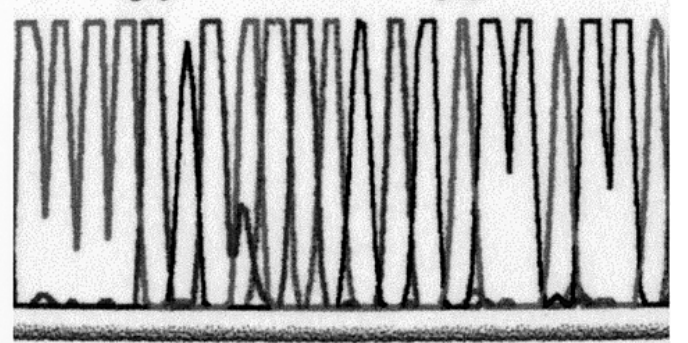

Codon 211

CAC(His) $\rightarrow$ TAC(Tyr)
B
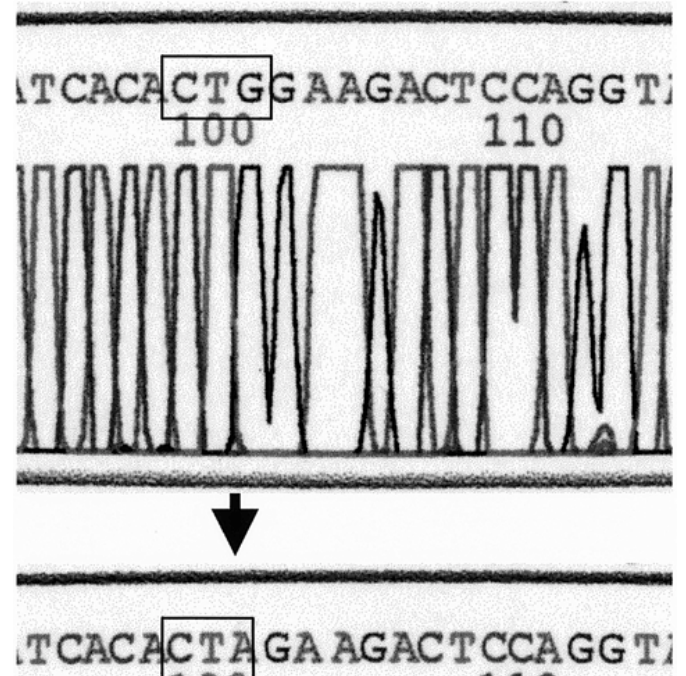
100 110

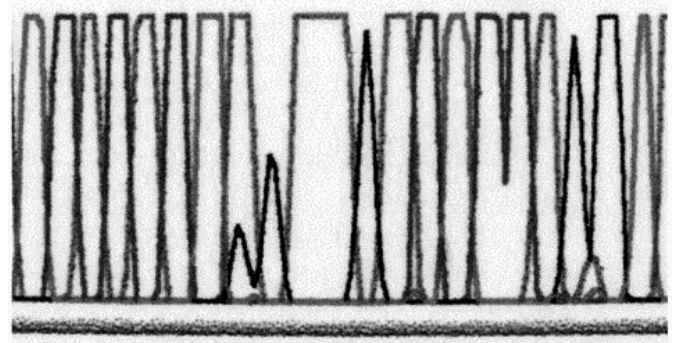

Codon 254

CTG (Leu) $\rightarrow$ CTA(Leu)

Fig. 2. (A) DNA sequencing of p53 exon 6 for the SCC from p53 (+/+) mouse. (Upper) Normal sequences; (lower) a CAC $\rightarrow \mathrm{TAC}$ mutation at codon 211 from a tumor. (B) DNA sequencing of p53 exon 7 for the papilloma from p53 (+/-) mouse. (Upper) Normal sequences; (lower) a CTG $\rightarrow$ CTA mutation at codon 254 from a tumor sample. 
$(+/-)$ mouse exhibited $\mathrm{CTG} \rightarrow \mathrm{CTA}(\mathrm{Leu} \rightarrow \mathrm{Leu})$ transition at codon 254 in exon 7, a silent mutation (Fig. 2B). Both mutations were $\mathrm{G}: \mathrm{C}$ to $\mathrm{A}: \mathrm{T}$ transitions. No mutation was detected in a CIS from p53 (+/-) mouse.

\section{Discussion}

In the present study, administration of MNAN, a genotoxic carcinogen ${ }^{24}$, to nullizygous p53 KO mice clearly demonstrated its carcinogenicity to tongue by an increased incidence of SCCs while heterozygous p53 KO mice and their wild-type counterparts were less susceptible to tongue carcinogenesis.

Although the number of nullizygous p53 KO mice without MNAN treatment was small in the present study, no spontaneous tongue neoplasms developed in any untreated nullizygous p53 KO mice. Furthermore, no spontaneous tongue lesions have been reported in nullizygous p $53 \mathrm{KO}$ mice $^{19}$. These imply that the lack of p53 function itself does not produce tongue neoplasms but results in an amplification of genetic alterations following DNA damage and consequent cancer development as supported by the fact that p53 regulates cell cycle arrest, nucleotide excision repair, and apoptosis ${ }^{1,4}$. Further study will be necessary to elucidate other genes implicated with tongue carcinogenesis in mice.

There was missense mutation of $\mathrm{p} 53$ gene in a CIS from wild-type mice treated with MNAN. The presence of p53 gene mutations have been reported in chemically induced tongue SCCs in xeroderma pigmentosum group A genedeficient mice ${ }^{25}$ and in hamsters ${ }^{26}$ as well as tongue SCCs in human $^{5,7}$. There seems to be involvement of p53 gene alterations for tongue carcinogenesis in a wide range of species. Although no p53 mutation was detected in a CIS from heterozygous p53 KO mice, it may have gone undetected in this study as a consequence of restricting the analysis to exons ${ }^{5-8}$.

The type of p53 mutation found in our study was G:C to A:T transitions. These patterns of mutations are the most prevalent types of p53 mutations in human SCC in oral cavity including tongue ${ }^{7,27}$. G:C to A:T transitions are also the most common mutations detected in hamster buccal pouch SCCs induced by N-methyl-N-benzylnitrosamine, being a potent alkylating carcinogen ${ }^{28}$.

The rare occurrence of tongue neoplasms in wild-type and heterozygous p53 $\mathrm{KO}$ mice in the present study might be a reflection of murine resistibility to tongue carcinogenesis. While 4-nitroquinoline-1-oxide (4NQO) is known to produce tongue carcinoma in rodents with variable susceptibility among species ${ }^{29}$, Ide et al. ${ }^{25}$ indicated that mice were resistant to administration of $4 \mathrm{NQO}$ at low concentrations (10 p.p.m.) via drinking water based on the fact that no neoplasms were induced in control mice treated with 4NQO via drinking water up to 2 years.

In contrast with the study using xeroderma pigmentosum group A gene-deficient mice treated with 4 NQO in which first tongue tumor was detected in experimental week $32^{25}$, tongue cancers developed earlier in nullizygous p53 KO mice given MNAN. Although consideration must be given to carcinogen specificity, the nullizygous p53 KO mice can be a useful model for identification and understanding of tongue carcinogens.

In conclusion, this study showed that nullizygous p53 deficiency enhanced tongue carcinogenesis in mice by the administration of MNAN and suggested that a lack of p53 gene function predisposed tongue to the development of SCC.

Acknowledgements: This work was supported in part by Grants-in-Aid from CREST (Core Research for Evolutional Science and Technology) of the Japan Science and Technology Corporation, by Grants-in-Aid for Cancer Research from the Ministry of Health, Labor and Welfare and by Grants-in-Aid from the Ministry of Education, Science, Sports, Culture and Technology of Japan.

\section{References}

1. Levine AJ. p53, the cellular gatekeeper for growth and division. Cell 1997; 88: 323-331.

2. Hollstein M, Rice K, Greenblatt MS, Soussi T, Fuchs R, Sorlie T, Hovig E, Smith-Sorensen B, Montesano R, and Harris CC. Database of p53 gene somatic mutations in human tumors and cell lines. Nucl Acids Res 1994; 22: 3551-3555.

3. Hollstein M, Sidransky D, Vogelstein B, and Harris CC. p53 mutations in human cancers. Science 1991; 253: 49-53.

4. Kuerbitz SJ, Plunkett BS, Walsh WV, and Kastan MB. Wild-type p53 is a cell cycle checkpoint determinant following irradiation. Proc Natl Acad Sci USA 1992; 89: 7491-7495.

5. Atula S, Kurvinen K, Grenman R, and Syrjanen S. SSCP pattern indicative for $\mathrm{p} 53$ mutation is related to advanced stage and high-grade of tongue cancer. Eur J Cancer B Oral Oncol 1996; 32B: 222-229.

6. Kropveld A, Rozemuller EH, Leppers FG, Scheidel KC, de Weger RA, Koole R, Hordijk GJ, Slootweg PJ, and Tilanus MG. Sequencing analysis of RNA and DNA of exons 1 through 11 shows p53 gene alterations to be present in almost $100 \%$ of head and neck squamous cell cancers. Lab Invest 1999; 79: 347-353.

7. Hsieh LL, Wang PF, Chen IH, Liao CT, Wang HM, Chen MC, Chang JTC, and Cheng AJ. Characteristics of mutations in the p53 gene in oral squamous cell carcinoma associated with betel quid chewing and cigarette smoking in Taiwanese. Carcinogenesis 2001; 22: 1497-1503.

8. Harvey M, McArthur MJ, Montgomery CA, Butel JS, Bradley A, and Donehower LA. Spontaneous and carcinogen-induced tumorigenesis in p53-deficient mice. Nat Genet 1993; 5: 225-229.

9. Jacks T, Remington L, Williams BO, Schmitt EM, Halachmi $\mathrm{S}$, Bronson RT, and Weinberg RA. Tumor spectrum analysis in p53-mutant mice. Curr Biol 1994; 4: 1-7.

10. Donehower LA. The p53-deficient mouse: a model for basic and applied cancer studies. Semin Cancer Biol 1996; 7: 269278.

11. Tennant RW, Spalding J, and French JE. Evaluation of transgenic mouse bioassays for identifying carcinogens and 
noncarcinogens. Mutat Res 1996; 365: 119-127.

12. Harvey M, McArthur MJ, Montgomery CA, Butel JS, Bradley A, and Donehower LA. Spontaneous and carcinogen-induced tumorigenesis in p53-deficient mice. Nature genetics 1993; 5: 225-229.

13. Kemp CJ, Donehower LA, Bradley A, and Balmain A. Reduction of p53 gene dosage does not increase initiation or promotion but enhances malignant progression of chemically induced skin tumors. Cell 1993; 74: 813-822.

14. Donehower LA, Harvey M, Vogel H, McArthur MJ, Montgomery CA, Park SH, Thompson T, Ford RJ, and Bradley A. Effects of genetic background on tumorigenesis in p53-deficient mice. Mol Carcinog 1995; 14: 16-22.

15. Tennant RW, French JE, and Spalding JW. Identifying chemical carcinogens and assessing potential risk in shortterm bioassays using transgenic mouse models. Environ Health Perspect 1995; 103: 942-950.

16. Donehower LA, Godley LA, Aldaz CM, Pyle R, Shi YP, Pinkel D, Gray J, Bradley A, Medina D, and Varmus HE. The role of p53 loss in genomic instability and tumor progression in a murine mammary cancer model. Prog Clin Biol Res 1996; 395: 1-11.

17. Preussmann R and Stewart BW. N-Nitroso carcinogens. In: Chemical Carcinogens, Searle CE (ed), Washington DC, 643-828, 1984.

18. Shirai N, Tsukamoto T, Yamamoto M, Iidaka T, Sakai H, Yanai T, Masegi T, Donehower LA, and Tatematsu M. Elevated susceptibility of the p53 knockout mouse esophagus to methyl-n-amylnitrosamine carcinogenesis. Carcinogenesis 2002; 23: 1541-1547.

19. Donehower LA, Harvey M, Slagle BL, McArthur MJ, Montgomery CA, Butel JS, and Bradley A. Mice deficient for $\mathrm{p} 53$ are developmentally normal but susceptible to spontaneous tumors. Nature 1992; 356: 215-221.

20. Tsukamoto T, Takahashi T, Ueda R, Hibi K, Saito H, and Takahashi T. Molecular analysis of the protein tyrosine phosphatase gamma gene in human lung cancer cell lines. Cancer Res 1992; 52: 3506-3509.

21. Orita M, Suzuki Y, Sekiya T, and Hayashi K. Rapid and sensitive detection of point mutations and DNA polymorphisms using the polymerase chain reaction. Genomics 1989; 5: 874-879.

22. Yamamoto M, Tsukamoto T, Sakai H, Shirai N, Ohgaki H, Furihata C, Donehower LA, Yoshida K, and Tatematsu M. p53 knockout mice (-/-) are more susceptible than $(+/-)$ or $(+/+)$ mice to $\mathrm{N}$-methyl-N-nitrosourea stomach carcinogenesis. Carcinogenesis 2000; 21: 1891-1897.

23. Rosner B. Fundamentals of Biostatistics. Belmont, CA: Duxbury Press, Wadsworth Publishing Co., 1995.

24. Mirvish SS, Huang Q, Williamson J, Chen SC, and Gelboin $\mathrm{HV}$. Use of monoclonal antibodies to cytochrome P450s to indicate the critical dealkylation and the P450s involved in methyl-n-amylnitrosamine mutagenicity in the presence of induced rat liver microsomes. Mutat Res 1995; 331: 161170.

25. Ide F, Oda H, Nakatsuru Y, Kusama K, Sakashita H, Tanaka $\mathrm{K}$, and Ishikawa $\mathrm{T}$. Xeroderma pigmentosum group A gene action as a protection factor against 4-nitroquinoline 1oxide-induced tongue carcinogenesis. Carcinogenesis 2001; 22: $567-572$.

26. Schwartz JL, Gu X, Kittles RA, Baptiste A, and Shklar G. Experimental oral carcinoma of the tongue and buccal mucosa: Possible biologic markers linked to cancers at two anatomic sites. Oral Oncol 2000; 36: 225-235.

27. Mirvish SS. Role of N-nitroso compounds (NOC) and Nnitrosation in etiology of gastric, esophageal, nasopharyngeal and bladder cancer and contribution to cancer of known exposures to NOC. Cancer Lett 1995; 93: $17-48$.

28. Chang KW, Sarraj S, Lin SC, Tsai PI, and Solt D. p53 expression, p53 and Ha-ras mutation and telomerase activation during nitrosamine-mediated hamster pouch carcinogenesis. Carcinogenesis 2000; 21: 1441-1451.

29. Ohne M, Satoh T, Yamada S, and Takai H. Experimental tongue carcinoma of rats induced by oral administration of 4-nitroquinoline 1-oxide (4NQO) in drinking water. Oral Surg Oral Med Oral Pathol 1985; 59: 600-607. 